\title{
PERSEPSI ORANG DEWASA TERHADAP KESEHATAN REPRODUKSI REMAJA AWAL (STUDI KASUS DI JALUR PANTAI UTARA, JAWA BARAT)
}

\author{
PERCEPTION OF ADULTS TOWARDS EARLY ADOLESCENTS' \\ REPRODUCTIVE HEALTH (A CASE STUDY IN NORTH COASTAL LINE OF \\ WEST JAVA)
}

\author{
Juariah \\ Badan Penelitian Dan Pengembangan Daerah Provinsi Jawa Barat
}

\begin{abstract}
This study aimed to explore adults' perceptions of early adolescents' reproductive health in North Coastal Line of West Java. This qualitative research was conducted in Pusakajaya Sub-District, Subang Regency on July 2017. Number of informants were 45 that were selected purposively. They are parents, teachers and community leaders. Data collection was conducted with Focus Group Discussion. The data was analyzed by content analysis. Results of this study showed that the main problems of the adolescents' reproductive health in North Coastal region were unintended pregnancy for girls and smoking and drug abuse for boys. Some problems that affected the adolescent reproductive health were the adolescents treated their friends as role models, difficulties for adults in communicating with adolescents related to reproductive health and limitation of curriculum, materials and teaching aids on reproductive health in schools. Poverty, negative environment and lack of attention from the local government were challenges that must be resolved. The solutions offered were strengthening family resilience, increasing school capacity in providing reproductive health education as well as continuous sensitization that is supported by the government policy. Exploring adults' perception of adolescent reproductive health was a form of involvement since the early stages of program design so that they can be effective partners in finding and meeting the adolescents' reproductive health needs.
\end{abstract}

Keywords: Perception, Adult, Early adolescents’ reproductive health

\section{ABSTRAK}

Penelitian ini bertujuan untuk mengeksplorasi persepsi orang dewasa tentang kesehatan reproduksi remaja awal di daerah Pantai Utara Jawa Barat. Penelitian kualitatif ini dilaksanakan di Kecamatan Pusakajaya Kabupaten Subang pada Bulan Juli 2017. Informan ditetapkan secara purposif yaitu orangtua, guru dan tokoh masyarakat berjumlah 45 orang. Pengumpulan data dilakukan dengan Diskusi Kelompok Terarah. Data yang terkumpul dianalisis dengan analisis isi. Hasil penelitian ini menunjukkan bahwa masalah utama kesehatan reproduksi remaja awal di daerah pantai utara adalah kehamilan yang tidak diinginkan untuk remaja putri dan merokok serta menggunakan NAPZA untuk remaja putra. Beberapa permasalahan yang berdampak terhadap kesehatan reproduksi remaja antara lain remaja menjadikan teman sebagai panutan, kesulitan orang dewasa berkomunikasi dengan remaja terkait kesehatan reproduksi, keterbatasan kurikulum, bahan dan alat bantu pengajaran kesehatan reproduksi di sekolah. Kemiskinan, lingkungan yang negatif dan kurangnya perhatian pemerintah setempat merupakan tantangan yang harus diselesaikan. Beberapa solusi yang ditawarkan adalah memperkuat ketahanan keluarga, meningkatkan kapasitas sekolah dalam memberikan pendidikan kesehatan reproduksi serta menyadarkan seluruh lapisan masyarakat secara terus menerus dengan didukung kebijakan pemerintah. Mengeksplorasi persepsi orang dewasa mengenai kesehatan reproduksi remaja awal dilakukan sebagai bentuk pelibatan sejak tahapan awal desain program agar mereka dapat menjadi mitra yang efektif dalam menemukan dan memenuhi kebutuhan kesehatan reproduksi remaja.

Kata Kunci: Persepsi, Orang dewasa, Kesehatan reproduksi remaja awal

\section{PENDAHULUAN}

Masa remaja, yang berada pada rentang usia 10-19 tahun, merupakan masa transisi dari kanak-kanak ke dewasa yang mana terjadi perubahan secara fisik, psikologis dan sosial 
(United Nations Population Fund \& Save the Children, 2009; Lloyd, 2005; Steinberg dan Morris, 2001). Pada masa ini seorang individu berkembang mencapai keterampilan dan atribut yang diperlukan untuk menjadi orang dewasa yang produktif dan reproduktif (Barker, 2007). Kelompok usia 10-14 tahun yang berada pada tahap remaja awal mengalami berbagai perubahan ini dengan cepat (Ortiz-Echevarria, L.dkk , 2017), munculnya tanda-tanda pematangan fisik (United Nations Population Fund \& Save the Children, 2009), penetapan identitas seksual dan gender dan juga perilaku kesehatan yang berdampak terhadap kesejahteraan mereka pada masa selanjutnya (OrtizEchevarria,L.dkk, 2017). Kualitas masa depan seorang remaja, sebagian besar, tergantung pada bagaimana kesuksesan mereka bernegosiasi melalui periode kritis ini (Lloyd, 2005).

Eksperimen dan pengambilan risiko merupakan hal normal selama masa remaja sebagai bagian dari proses pengembangan keterampilan pengambilan keputusan (United Nations Population Fund \& Save the Children, 2009). Namun perilaku beresiko ini dapat memiliki konsekuensi seumur hidup bagi kesehatan dan kesejahteraan
(Barker, 2007). Hal ini karena sebagian eksperimen yang dilakukan remaja dapat berupa eksperimen yang negatif seperti bereksperimen dengan sex, zatzat seperti alkohol, tembakau atau obatobatan (United Nations Population Fund \& Save the Children, 2009). Perilaku ini dapat memerangkap remaja ke dalam satu atau lebih masalah kesehatan reproduksi remaja yang dikenal dengan triad Kesehatan Reproduksi Remaja yaitu seksualitas (Save the Children, 2004), Penyakit Menular Seksual dan Human Immunodeficiency Virus/Acquired ImmunoDeficiency Syndrome (HIV/AIDS) (Kementerian Kesehatan Republik Indonesia, 2015) dan penyalahgunaan Narkotika, Psikotropika dan Zat Adiktif Lainnya ( NAPZA).

Orang dewasa memegang peranan kunci dalam membentuk sikap dan perilaku remaja (Kibombo, R.dkk, 2008). Meskipun masa remaja merupakan saat dimana remaja beranjak dari kanak-kanak untuk mengambil peran dan tanggung jawab sendiri sebagai orang dewasa, orangtua dan anggota keluarga yang lain, dan juga orang dewasa lainnya seperti tenaga kesehatan, guru dan tokoh masyarakat, melalui norma-norma dan nilai-nilai 
yang ditanamkan, mempengaruhi pilihan dan keputusan yang dibuat oleh remaja dan berkontribusi untuk membentuk pengetahuan, sikap dan perilaku mereka (Kibombo, dkk, 2008; Lloyd, 2005). Orang dewasa juga memainkan peran penting untuk membantu remaja mempertimbangkan konsekuensi dari perilaku mereka (terutama perilaku berisiko) dan membantu mereka mengidentifikasi pilihan (United Nations Population Fund \& Save the Children, 2009), termasuk dalam mengambil keputusan terkait kesehatan reproduksi dan seksual (Lloyd, 2005; Rafidah dkk, 2009). Pengaruh positif dari orang dewasa adalah faktor pelindung bagi remaja dan dapat membantu remaja mengatasi stres dan mengembangkan ketahanan dirinya (United Nations Population Fund \& Save the Children, 2009). Bahkan, orang dewasa merupakan penjaga gawang karena peran penting mereka sebagai penyaring informasi dan pelayanan kesehatan reproduksi untuk remaja (Kumi-kyereme, A.dkk, 2014).

Remaja yang bertempat tinggal di daerah kecamatan - kecamatan Kabupaten Subang yang dilalui Jalur Pantai Utara Jawa Barat seperti Kecamatan Pusakajaya, memiliki resiko lebih tinggi mengalami masalahmasalah kesehatan reproduksi. Hal ini karena di sepanjang jalur ini ada banyak motel, kafe dan warung-warung yang pada malam hari berubah fungsi menjadi tempat transaksi seksual. Selain itu di kecamatan ini juga ada lokalisasi Genteng dan Patimban. Lingkungan seperti ini dapat memberikan pengaruh negatif pada remaja yang bertempat tinggal di daerah tersebut. Daerah jalur pantai utara juga memiliki prevalensi HIV/AIDS yang tinggi (Heriana,C.dkk, 2015). Total penderita HIV/AIDS di Kabupaten Subang mencapai 1766 orang (Putra,W, diakses 15 Juli 2019) dan sebagian besar kasus ditemukan di daerah pantai utara. Selain itu sekitar $30 \%$ berada pada kelompok usia remaja (Rahmawati, L., diakses 15 Juli 2019). Pengasuhan orangtua yang lemah karena banyaknya orangtua yang menjadi Tenaga Kerja Indonesia di luar negeri serta tingkat perceraian orangtua yang tinggi memungkinkan remaja di daerah ini terjerumus ke dalam seks bebas, narkoba, dan terinfeksi HIV (Pemerintah Daerah Kabupaten Subang, 2009).

Persepsi adalah produk akhir dari interaksi antara rangsangan dan hipotesis internal, harapan dan 
pengetahuan pengamat, yang mana motivasi dan emosi memainkan peran penting dalam proses ini (Demuth, 2013). Berbagai penelitian yang berkaitan dengan persepsi orang dewasa terhadap kesehatan reproduksi remaja antara lain penelitian yang dilakukan terhadap orangtua mengenai pengetahuan, sikap dan persepsi mereka mengenai kesehatan reproduksi remaja (Rafidah dkk, 2009; Svodziwa dkk, 2016; Olubayo-Fatiregun, 2012; Mohammadi Mohammad-Reza dkk, 2007; Nundwe, 2012). Penelitian lain yang dilakukan oleh Kyereme dkk (2014), Kibombo dkk (2008), Echevarria dkk (2017) mengeksplorasi persepsi orang dewasa bukan hanya orangtua tetapi juga guru, tenaga kesehatan dan tokoh masyarakat terkait kesehatan reproduksi remaja. Sedangkan penelitian yang dilakukan oleh Boamah-kaali dkk (2018) di dua rumah sakit di kota Kintampo, Ghana bertujuan untuk mengkaji pendapat tenaga kesehatan mengenai kesesuaian pelayanan kesehatan reproduksi dan seksual dengan kebutuhan remaja.

Mengingat pentingnya peran orang dewasa dalam menemukan dan menyelesaikan masalah kesehatan reproduksi remaja dan belum optimalnya pelibatan orang dewasa dalam program kesehatan reproduksi remaja khususnya di daerah Pantai Utara maka penulis tertarik untuk melakukan penelitian mengenai persepsi orang dewasa tentang kesehatan reproduksi remaja awal di daerah pantai utara Jawa Barat. Orang dewasa yang dilibatkan dalam ini adalah orangtua, guru dan tokoh masyarakat. Hal ini dengan pertimbangan bahwa orangtua, guru dan tokoh masyarakat adalah orang dewasa yang paling intens berhubungan dengan remaja. Secara khusus, penelitian ini bertujuan untuk mengeksplorasi persepsi orang dewasa mengenai: masalah utama kesehatan reproduksi remaja di daerah pantai utara; hambatan dan tantangan yang berdampak terhadap kesehatan reproduksi remaja serta solusi yang mereka tawarkan untuk menyelesaikan masalah-masalah kesehatan reproduksi remaja.

\section{METODE}

Penelitian ini menggunakan pendekatan deskriptif kualitatif. Hal ini dipilih dengan pertimbangan penelitian ini memerlukan penjelasan yang detil mengenai satu fenomena dan hanya dapat dilakukan dengan mendengarkan 
secara langsung suara atau pendapat orang-orang. Penelitian dilaksanakan di Kecamatan Pusakajaya Kabupaten Subang, Jawa Barat pada bulan Juli 2017. Alasan pemilihan tempat ini adalah karena kecamatan ini berada di Jalur Pantai Utara Jawa Barat. Informan penelitian ini ditetapkan secara purposif yaitu orangtua yang memiliki remaja awal yang bersekolah di SMPN 1 dan SMPN 2 Pusakajaya, direkomendasikan oleh pihak sekolah dan bersedia menjadi partisipan dalam kegiatan ini. Informan lain adalah guru yang mengajar di SMPN 1 atau di SMPN 2 Pusakajaya. Mereka adalah kepala sekolah, wakil Tabel 1. Karakteristik Informan kepala sekolah bidang kurikulum, wakil kepala sekolah bidang kesiswaan, guru bimbingan dan konseling (BK), guru mata pelajaran agama, IPA, pendidikan jasmani, olahraga dan kesehatan, Selain itu tokoh masyarakat yang dilibatkan adalah ketua dan pengurus rukun warga dan pengurus masjid dimana anak-anak remaja mendapat kesempatan untuk belajar mengaji.

Jumlah informan penelitian adalah 45 orang terdiri dari 18 orang guru, 22 orangtua dan 5 orang tokoh masyarakat. Mengenai karakteristik informan dapat dilihat pada tabel berikut ini.

\begin{tabular}{|c|c|c|c|c|c|}
\hline $\begin{array}{l}\text { No } \\
\text { Informan }\end{array}$ & $\begin{array}{l}\text { Umur } \\
\text { (Tahun) }\end{array}$ & $\begin{array}{l}\text { Jenis } \\
\text { Kelamin }\end{array}$ & Pendidikan & Pekerjaan & Status \\
\hline 1 & 52 & Wanita & Sarjana & Guru IPA & $\begin{array}{l}\text { Guru SMPN } 1 \\
\text { Pusajakaya }\end{array}$ \\
\hline 2 & 53 & Pria & Sarjana & Guru IPA & \\
\hline 3 & 49 & Pria & Sarjana & $\begin{array}{l}\text { Wakil Kepala Sekolah Bidang } \\
\text { Kesiswaan }\end{array}$ & \\
\hline 4 & 49 & Pria & Sarjana & Guru Agama & \\
\hline 5 & 51 & Wanita & Sarjana & Guru BK & \\
\hline 6 & 47 & Wanita & Sarjana & $\begin{array}{l}\text { Wakil Kepala Sekolah Bidang } \\
\text { Kurikulum }\end{array}$ & \\
\hline 7 & 51 & Wanita & Sarjana & Guru BK & \\
\hline 8 & 45 & Pria & Sarjana & Guru Olahraga & \\
\hline 9 & 52 & Pria & Sarjana & Kepala Sekolah & \\
\hline 10 & 35 & Pria & Sarjana & $\begin{array}{l}\text { Wakil Kepala Sekolah Bidang } \\
\text { Kesiswaan }\end{array}$ & $\begin{array}{l}\text { Guru SMPN } 2 \\
\text { Pusakajaya }\end{array}$ \\
\hline 11 & 35 & Pria & Sarjana & Guru BK & \\
\hline 12 & 32 & Wanita & Sarjana & Guru IPA & \\
\hline 13 & 48 & Pria & Sarjana & Guru Olahraga & \\
\hline 14 & 52 & Pria & Sarjana & Kepala Sekolah & \\
\hline 15 & 35 & Wanita & Sarjana & $\begin{array}{l}\text { Wakil Kepala Sekolah Bidang } \\
\text { Kurikulum }\end{array}$ & \\
\hline 16 & 34 & Pria & Sarjana & Guru Olahraga & \\
\hline 17 & 50 & Pria & Sarjana & Guru Agama & \\
\hline 18 & 28 & Wanita & Sarjana & Guru IPA & \\
\hline 19 & 45 & Wanita & SMA & Ibu Rumah Tangga & $\begin{array}{l}\text { Orangtua } \\
\text { SMPN }\end{array}$ \\
\hline
\end{tabular}




\begin{tabular}{|c|c|c|c|c|c|}
\hline & & & & & Pusakajaya \\
\hline 20 & 38 & Wanita & SMP & Ibu Rumah Tangga & \\
\hline 21 & 42 & Wanita & SMP & Ibu Rumah Tangga & \\
\hline 22 & 52 & Wanita & $\mathrm{SD}$ & Dagang di warung & \\
\hline 23 & 46 & Wanita & SD & Dagang di warung & \\
\hline 24 & 51 & Pria & SD & Petani & \\
\hline 25 & 43 & Wanita & SD & Ibu Rumah Tangga & \\
\hline 26 & 48 & Pria & SD & Petani & \\
\hline 27 & 39 & Wanita & SMP & Ibu Rumah Tangga & \\
\hline 28 & 42 & Pria & SMA & Wiraswasta/bengkel & \\
\hline 29 & 41 & Wanita & Sarjana & Guru SD & \\
\hline \multirow[t]{2}{*}{30} & 50 & Pria & $\mathrm{SD}$ & Petani & Orangtua \\
\hline & & & & & $\begin{array}{l}\text { SMPN } \\
\text { Pusakajaya }\end{array}$ \\
\hline 31 & 49 & Wanita & SD & Ibu Rumah Tangga & \\
\hline 32 & 38 & Pria & SMA & Wiraswasta & \\
\hline 33 & 32 & Wanita & SMP & Ibu Rumah Tangga & \\
\hline 34 & 35 & Wanita & SMP & Ibu Rumah Tangga & \\
\hline 35 & 38 & Wanita & SMP & Ibu Rumah Tangga & \\
\hline 36 & 42 & Pria & $\mathrm{SD}$ & Petani & \\
\hline 37 & 45 & Pria & SMA & Wiraswasta & \\
\hline 38 & 48 & Pria & SD & Petani & \\
\hline 39 & 34 & Wanita & $\mathrm{SD}$ & Ibu Rumah Tangga & \\
\hline 40 & 45 & Pria & SMP & Petani & \\
\hline \multirow[t]{2}{*}{41} & 60 & Pria & $\mathrm{SD}$ & Petani/Pengurus DKM & Tokoh masyarakat \\
\hline & & & & & $\begin{array}{ll}\text { SMPN } & 1 \\
\text { Pusakajaya } & \end{array}$ \\
\hline 42 & 48 & Pria & SD & Petani/RW & \\
\hline 43 & 55 & Pria & SD & Petani/Pengurus DKM & \\
\hline \multirow[t]{3}{*}{44} & 52 & Pria & SD & Petani/RW & Tokoh masyarakat \\
\hline & & & & & SMPN 2 \\
\hline & & & & & Pusakajaya \\
\hline 45 & 65 & Pria & SMP & Petani/Pengurus DKM & \\
\hline
\end{tabular}

Sumber: data primer

Berdasarkan tabel 1 dapat dilihat bahwa informan guru semuanya berpendidikan sarjana, berada pada rentang umur 28 tahun sampai 53 tahun terdiri dari 11 pria dan 7 wanita. Sedangkan informan orangtua terdiri dari 13 orang wanita (ibu) dan 9 orang pria (ayah). Mereka berada pada rentang usia 34 sampai 52 tahun. Tingkat pendidikan yang diselesaikan adalah SD (10 orang), SMP (8 orang) dan SMA (4 orang). Mereka bekerja sebagai Ibu Rumah Tangga (10 orang), Petani (6 orang), pedagang (2 orang), guru (1 orang), wiraswasta (3 orang). Adapun tokoh masyarakat semuanya pria, rentang usia antara 48 sampai 65 tahun, 4 orang berpendidikan SD dan hanya 1 orang yang lulus SMP dan semuanya bekerja sebagai petani selain menjadi pengurus RW/DKM.

Pengumpulan data dilakukan dengan cara Diskusi Kelompok Terarah (DKT), dengan pembagian kelompok sebagai berikut: 
Tabel 2. Informan Diskusi Kelompok Terarah

\begin{tabular}{lcc}
\hline \multicolumn{1}{c}{ Kategori Informan } & Kelompok & Jumlah informan \\
\hline Guru yang mengajar di SMPN 1 Pusakajaya & 1 & 9 \\
Guru yang mengajar di SMPN 2 Pusakajaya & 1 & 9 \\
Orangtua siswa dan tokoh masyarakat yang bertempat tinggal di sekitar & 1 & 14 \\
SMPN 1 Pusakajaya & & 13 \\
Orangtua siswa dan tokoh masyarakat yang bertempat tinggal di sekitar & 1 & \\
SMPN 2 Pusakajaya & & \\
\hline
\end{tabular}

Sumber: data primer

Kegiatan DKT dilakukan setelah mendapatkan izin etik dari Komisi Etik Penelitian Fakultas Kedokteran, Universitas Padjajaran. Selain itu, sebelum dilakukan diskusi, calon informan diberi penjelasan mengenai kegiatan penelitian dan dimintakan persetujuan. Kepada calon informan juga diyakinkan mengenai anonimitas dan kerahasiaan data yang diberikan. Dengan seizin informan, proses DKT direkam dan topik diskusi dicatat oleh notulen. Kegiatan DKT dipandu oleh peneliti dengan dibantu oleh satu orang notulen yang mencatat keseluruhan proses diskusi terutama pertanyaan dan tanggapan dari informan, satu orang yang mengoperasikan rekaman video dan satu orang yang menjadi observer. Untuk melengkapi dokumentasi, proses diskusi juga direkam dengan rekaman audio.
Kegiatan DKT dilaksanakan di salah satu ruangan kelas SMPN 1 Pusakajaya untuk guru dan orangtua siswa/tokoh masyarakat SMPN 1 Pusakajaya dan di salah satu ruangan kelas SMPN 2 Pusakajaya untuk guru dan orangtua siswa/tokoh masyarakat SMPN 2 Pusakajaya. Kegiatan ini dilaksanakan pada siang menjelang sore hari setelah kegiatan pembelajaran di sekolah selesai. Setiap sesi DKT mengambil waktu sekitar 120 menit. Data yang terkumpul dibuat transkrip kemudian diolah dan dianalisis dengan menggunakan analisis isi (content Anlysis). Analisis isi adalah teknik penelitian untuk membuat kesimpulan yang dapat ditiru (replicable) dan valid dari teks atau sumber lain yang bermakna sesuai dengan konteks penggunaannya (Krippendorff,K., 2004). Menurut Hsieh dan Shannon (2005), analisis isi merupakan metode 
penelitian untuk interpretasi subyektif dari isi data teks melalui proses klasifikasi sistematis pengkodean dan identifikasi tema atau pola. Sehingga tahapan analisis isi dimulai dengan membaca semua data berulang kali, kemudian data dibaca kata demi kata untuk mendapatkan kode. Selanjutnya kode diurutkan ke dalam kategori berdasarkan bagaimana kode yang berbeda terkait dan ditautkan. Tahapan berikutnya adalah mengkaji ulang kategori apakah ada yang dapat digabungkan atau yang perlu disubkategorikan. Terakhir, kembali ke transkrip asli dan meyakinkan kembali bahwa semua informasi yang dibutuhkan telah dikategorikan (Hsieh, HF., Shannon, 2005). Data yang sudah diolah dan dianalisis disajikan dalam bentuk narasi dan kutipan.

\section{HASIL DAN PEMBAHASAN}

Ada tiga tema utama yang muncul dalam kegiatan Diskusi Kelompok Terarah ini yaitu masalah utama kesehatan reproduksi remaja, hambatan dan tantangan yang berdampak terhadap kesehatan reproduksi remaja serta solusi yang ditawarkan orang dewasa untuk menyelesaikan masalah kesehatan reproduksi remaja.

\section{Masalah Utama Kesehatan}

\section{Reproduksi Remaja}

Semua informan sependapat bahwa permasalahan kesehatan reproduksi remaja putri yang terjadi di daerah mereka adalah kehamilan yang tidak diinginkan.

\footnotetext{
"Pada tahun 2016, ada 13 orang siswa putri yang keluar sekolah, karena hamil. Ada yang masih di kelas VIII, beberapa orang sudah kelas IX. Sebenarnya pihak sekolah tidak mengeluarkan mereka, apalagi dengan sekarang sudah ada wajib sekolah 9 tahun, kami ingin mempertahankan mereka untuk tetap sekolah. Kami sampai mendatangi ke rumah, berbicara dengan orangtuanya, tidak apa-apa menikah tapi tetap sekolah harus diselesaikan, tapi tetap orangtua dan anaknya tidak mau. Alasannya malu."

(Guru, DKT)
}

Para informan menjelaskan bahwa kehamilan remaja ini terjadi sebagai akibat dari pergaulan bebas. Menurut mereka para remaja putri ini kebanyakan hamil karena berpacaran dengan artis 'arak-arakan' (kesenian khas dari Subang Utara yang mana para artisnya adalah laki-laki muda usia yang mengarak tandu berbentuk hewanhewan laut. Mereka menari dan berjoget diiringi dengan musik modern yang menghentak dan lagu-lagu jawa cirebonan).

\footnotetext{
“Anak-anak baru remaja itu bangga kalau punya pacar artis arak-arakan, padahal sebagian besar mereka itu sudah beristri, mereka ga peduli. Bahkan sampai mereka 'diapa-apain' mereka mau. Sampai
} 
mereka hamil. Mereka kadang dinikahi, tapi biasanya hanya sebentar, setelah itu diceraikan, merepotkan lagi orangtua, karena mereka belum bisa mengurus anak" (Orangtua, DKT).

Sementara masalah yang banyak terjadi pada remaja putra, menurut para informan, adalah merokok dan narkoba.

\section{"Di daerah ini banyak anak laki-laki yang sudah merokok sejak SD. Kalau di SMP, mereka sudah banyak yang menggunakan narkoba, mereka 'ngelem', 'ngomix', tape saja bisa mereka bikin buat mabuk- mabukan" (orangtua, DKT).}

Hasil penelitian ini sejalan dengan hasil penelitian yang dilakukan oleh Kibombo dkk (2008) di Uganda dan Awusabo-Asare dkk (2008) di Ghana. Kondisi ini akan memberikan akibat buruk pada remaja tersebut karena peningkatan resiko mengalami kematian akibat kehamilan dan persalinan dua kali lebih tinggi dibanding perempuan yang lebih tua (United Nations Population Fund \& Save the Children, 2009; Save the Children, 2004; Blum dkk, 2014). Hal ini disebabkan karena berbagai penyulit yang dapat muncul pada kehamilan remaja (United Nations Population Fund \& Save the Children, 2009; Lloyd, 2005; Pusat data dan Informasi Kementerian Kesehatan RI, 2014). Bayi yang dilahirkan ibu remaja dapat mengalami lahir prematur dan Berat Badan Lahir Rendah (BBLR) yang berkontribusi terhadap tingginya kematian perinatal (Badan penelitian dan pengembangan kesehatan, 2008). Hal ini diperkuat dengan hasil penelitian yang dilakukan oleh Latifah dan Anggraeni (2013) pada 62 orang remaja yang melahirkan di Rumah Sakit Margono Soekarjo Purwokerto yang menemukan bahwa ibu remaja beresiko lebih tinggi untuk melahirkan prematur dan BBLR (masing-masing 3,88 kali dan 7 kali) dibanding ibu yang sudah dewasa. Selain berdampak pada fisik dan kesehatan, remaja perempuan yang hamil juga terpaksa harus keluar sekolah dan biasanya mereka tetap tidak kembali sekolah setelah melahirkan (Kumi-kyereme, A. dkk, 2014). Hal ini akan menjadikan mereka kehilangan kesempatan untuk menata masa depannya.

Berbeda dengan remaja perempuan, masalah yang banyak terjadi pada remaja laki-laki di daerah pantai utara adalah merokok dan menggunakan NAPZA. Hal ini sejalan dengan hasil penelitian Mumthas \& Shamina (2016) di Kerrala, India. Merokok, konsumsi alkohol, dan penggunaan obat-obatan terlarang adalah beberapa perilaku yang memiliki efek paling merusak pada kesehatan 
jangka panjang (Lloyd, 2005). Hal ini karena selain menimbulkan gangguan kesehatan fisik (Komasari, D. Helmi, 2000); juga memicu masalah psikologis (Moylan dkk., 2013; Rondina, CR.dkk, 2007). Narkoba juga menjadikan remaja malas belajar, kehilangan konsentrasi dan berperilaku negatif (World Health Organization, 2014). Selain itu juga dapat meluas ke perilaku beresiko yang lain, termasuk aktivitas seksual dini (Lloyd, 2005).

\section{Hambatan dan Tantangan yang berdampak terhadap Kesehatan Reproduksi Remaja}

Para informan mengakui bahwa remaja lebih menjadikan sebaya mereka sebagai panutan.

"Anak-anak lebih suka mendengar apa kata temannya, daripada apa kata orangtua. Kalau temannya baik, anak kita bisa kebawa baik, tapi pas ketemu temannya yang tidak baik, bisa ikutan tidak baik juga" (orangtua, DKT).

“Anak-anak itu sangat ingin diakui oleh teman-temannya. Di sekolah juga biasanya berawal dari geng- gengan. Anak yang merokok itu biasanya karena temannya memang merokok juga. Kalau ga ikutan mereka takut dibilang banci atau apa gitu” (Guru, DKT).

Menjadikan sesama remaja sebagai panutan dan keinginan diakui oleh sebaya yang disampaikan informan dalam penelitian ini sejalan dengan hasil-hasil penelitian lain seperti penelitian Geckova dkk (2002), Komasari \& Helmi (2000) dan Cheruiyot dkk (2013). Teman sebaya memiliki pengaruh yang kuat (Lloyd, 2005; United Nations Population Fund $\&$ Save the Children, 2009). Adamchak dkk (2000) menegaskan bahwa remaja yang berteman dengan yang melakukan seks bebas, merokok dan pengguna NAPZA, juga cenderung berperilaku yang sama. Hasil penelitian lain yang dilakukan oleh Masroah dkk (2015) juga mendapatkan bahwa remaja menggunakan media pornografi salah satunya karena pengaruh teman.

Selain itu orang dewasa juga mengalami kendala pada saat mereka berkomunikasi dengan anak remaja terkait kesehatan reproduksi remaja.

"Saya risih kalau harus berbicara tentang masa puber sama anak-anak. Apalagi sama anak gadis, masa harus cerita tentang menstruasi, hamil. Biar aja mereka tahu sendiri nanti juga" (Orangtua, DKT).

Hambatan berkomunikasi dengan remaja terkait isu kesehatan reproduksi yang ditemukan dalam penelitian ini juga terjadi pada penelitian sebelumnya seperti penelitian yang dilakukan oleh Muhwezi dkk (2015), Nundwe (2012), Svodziwa dkk, 2016), (Mohammadi Mohammad-Reza 
dkk (2007), Kumi-kyereme,A.dkk (2014). Ketidaknyamanan orangtua dan remaja dalam membicarakan kesehatan reproduksi remaja dapat mencegah terjadinya komunikasi kesehatan reproduksi yang efektif. Padahal, komunikasi dalam keluarga merupakan hal yang sangat penting selama masa remaja khususnya terkait isu kesehatan reproduksi. Hal ini karena remaja sering terlibat dalam perilaku seksual beresiko yang dapat berakibat pada konsekuensi kesehatan, sosial dan ekonomi yang merugikan (Nundwe, 2012).

Berdasarkan pengalaman para guru terdapat perbedaan dalam memberikan informasi tentang kesehatan reproduksi. Hal ini terjadi karena keterbatasan referensi dalam kurikulum, bahan dan alat bantu pengajaran.

"Dalam kurikulum sekarang, materi tentang kesehatan reproduksi sedikit. Itu juga baru diajarkan di kelas VIII dan kelas IX. Terlalu terlambat. Karena banyak anak yang sudah bermasalah sejak kelas VII. Harusnya dasar-dasarnya sudah diajarkan sejak awal. Seperti resiko kehamilan pada remaja, bahaya merokok, bahaya narkoba. Alat bantu mengajarnya juga bisa dibilang tidak ada. Jadi akhirnya kita mengajar ke anak-anak sesuai yang kita tahu saja, waktunya juga kadang kita selipkan dalam mata pelajaran, atau di luar jam pelajaran missal dalam ekskul pramuka, PMR..." (Guru, FGD).

Keterbatasan referensi dalam kurikulum, bahan dan alat bantu pengajaran terkait kesehatan reproduksi remaja yang dialami para guru dalam penelitian ini sejalan dengan hasil penelitian yang dilakukan oleh Kibombo dkk (2008). Pada kurikulum pendidikan Sekolah Menengah Pertama (SMP) tahun 2013 hanya ada 3 mata pelajaran yang terkait dengan kesehatan yaitu mata pelajaran Ilmu Pengetahuan Alam (IPA), Pendidikan Jasmani, Olahraga dan Kesehatan dan Agama. Topik kesehatan reproduksi yang diajarkan pada kelas VIII dan IX yaitu tentang dampak hubungan seks bebas, NAPZA, Penyakit Menular Seksual dan pencegahannya

(Kementerian Pendidikan dan Kebudayaan RI, 2012). Lemahnya peran sekolah, didukung oleh kondisi lingkungan di pantai utara dapat mendorong remaja untuk melakukan perilaku beresiko. Hal ini sebagaimana ditegaskan oleh OlubayoFatiregun (2012) bahwa informasi yang kurang memadai dapat mendorong remaja untuk meniru dan mempraktikkan apa pun yang mereka tonton, lihat, dengar, atau baca dari sumber lain.

Para informan mengakui bahwa ada berbagai kondisi yang secara tidak langsung memberikan dampak negatif terhadap kesehatan reproduksi remaja di 
daerah mereka. Kemiskinan, lingkungan sekitar dominan menjadikan banyak orangtua yang memilih untuk bekerja di kota bahkan di luar negeri, dengan harapan mendapat penghasilan lebih tinggi. Anak-anak yang sedang tumbuh remaja, dititipkan pada nenek kakeknya atau famili yang lain. Akibatnya banyak anak yang kurang mendapat kasih sayang dan pengawasan dari orang dewasa terdekat.

\begin{abstract}
"Siswa yang lahir dari keluarga ekonomi lemah, banyak yang tidak tinggal dengan orangtuanya. Ada yang ibunya menjadi Tenaga Kerja Wanita di luar negeri, banyak juga yang jadi pembantu di kota. Anak tinggal dengan neneknya, atau bibinya, yang kurang memberikan pengawasan juga. Akhirnya anak salah pergaulan" (Guru, DKT).
\end{abstract}

Para informan mengungkapkan faktor lain yang juga memberi pengaruh negatif pada remaja adalah lingkungan tempat tinggal para remaja tersebut.

"Lingkungan disini buruk sekali untuk anak-anak yang masih mencari jati diri. Makin banyaknya kafe di pinggir jalan, yang mana disitu banyak wanita yang menjajakan diri, banyak sopir truk yang mampir, memberikan pemandangan negatif untuk anak-anak. Bisa jadi mereka penasaran...." (Tokoh masyarakat, DKT).

Tuntutan ekonomi yang menjadikan banyak orangtua di daerah pantai utara memilih untuk bekerja sebagai tenaga kerja Indonesia di luar negeri atau buruh di kota menjadikan mempengaruhi para remaja. Hal ini sejalan dengan pendapat Bakker dkk (2009), Blum dkk (2014), United Nations Population Fund \& Save the Children (2009) bahwa Para remaja yang tidak tinggal dalam pengawasan orangtua ini memiliki potensi lebih tinggi untuk memilih perilaku beresiko. Pengaruh lingkungan negative terhadap remaja ditegaskan oleh Adamchak dkk (2000) bahwa potensi berperilaku negatif remaja juga didukung oleh lingkungan dengan keberadaan industri seks dan akses luas ke tempat-tempat hiburan seperti bar dan diskotik.

Selain itu, kurangnya perhatian dari pemerintah setempat untuk memberikan lingkungan yang kondusif untuk remaja menjadikan makin maraknya pengaruh negatif dari lingkungan.

"Disini kalau habis panen, atau ada nikahan, atau 17 agustusan, atau malah hari-hari biasa pun sering sekali ada pesta reggae. Di pesta itu biasanya ada musik-musik, ada penyanyinya juga, anak-anak muda berjoget. Disitu biasanya banyak yang mabuk-mabukkan. Itu disiarkan pake pengeras suara keliling kecamatan. Jadi anak-anak tahu semua. Malah beberapa kali waktunya anak-anak ujian sekolah. Namanya juga anak-anak, mereka penasaran. Pada datang kesana. Disitu mereka coba-coba pake narkoba yang ditawarkan gratis. Tapi acara-acara seperti itu malah dikasih 
izin, dilindungi oleh aparat..." (Guru, DKT).

Dukungan pemerintah setempat terhadap dominasi lingkungan yang negatif memperbesar resiko remaja di daerah ini. Sebaliknya, kebijakan yang positif dapat melindungi remaja dari resiko kesehatan reproduksi dan seksual (Adamchak dkk, 2000). Oleh karena itu, memperbaiki lingkungan sosial, dengan terlebih dahulu mempengaruhi teman sebaya, mitra, keluarga, lembaga, dan anggota masyarakat menjadi sangat penting untuk mendukung remaja mampu membuat keputusan sehat.

\section{Solusi yang Ditawarkan Orang}

\section{Dewasa Dalam Menghadapi Masalah}

\section{Kesehatan Reproduksi Remaja}

Para informan menyampaikan beberapa solusi yang dapat membantu menyelesaikan masalah kesehatan reproduksi remaja. Memperkuat ketahanan keluarga merupakan hal yang paling penting menurut mereka.

"Idealnya anak harus ada dalam perlindungan dan kasih sayang kedua orangtuanya. Kalaupun tidak, jika tinggal dengan salah satu orangtua atau tinggal dengan keluarga yang lain, harus memberi perhatian pada remaja, bukan hanya makan pakaiannya, tapi juga akhlaknya, sekolahnya..." (Tokoh masyarakat, DKT).
Sekolah sebagai sumber informasi formal utama di daerah ini, diharapkan oleh para informan dapat memiliki kapasitas yang memadai untuk memberikan informasi mengenai kesehatan reproduksi.

\footnotetext{
"Kami percaya dan berharap sekolah menjadi sumber untuk anak-anak mendapatkan ilmu yang benar tentang bahaya merokok, narkoba, pergaulan bebas..." (Orangtua, DKT).
}

Menyadarkan seluruh lapisan masyarakat secara terus menerus dengan didukung oleh kebijakan pemerintah merupakan upaya lain yang harus dilakukan.

"Harus ada kebijakan pemerintah yang mendukung, masyarakat juga harus peduli bahwa remaja itu adalah tanggung jawab kita. Kalau remaja kita bermasalah maka yang dirugikan adalah kita semua karena generasi penerus kita yang rusak" (Guru, DKT).

Hasil penelitian ini sejalan dengan pendapat Adamchak dkk (2000) dan Blum dkk (2014) bahwa memperkuat ketahanan keluarga merupakan salahsatu upaya untuk melindungi remaja dari perilaku beresiko dan meningkatkan kualitas dan kuantitas pendidikan remaja melalui sekolah dapat meningkatkan kesehatan reproduksi remaja. Pentingnya sensitisasi yang disampaikan informan juga sesuai 
dengan hasil penelitian Kibombo dkk (2008). Sedangkan Peraturan Pemerintah nomor 61 Tahun 2014 tentang Kesehatan Reproduksi diantaranya mengatur peran pemerintah pusat, provinsi dan kabupaten/kota terkait kesehatan reproduksi secara umum diantaranya adalah bertanggungjawab terhadap penyelenggaraan sistem informasi dan penyelenggaraan pelayanan kesehatan termasuk kesehatan reproduksi remaja.

\section{SIMPULAN DAN SARAN}

Hasil penelitian menemukan bahwa masalah utama kesehatan reproduksi remaja di daerah pantai utara adalah kehamilan yang tidak diinginkan dan penggunaan NAPZA dan merokok. Sedangkan permasalahan yang berdampak terhadap kesehatan reproduksi remaja adalah kemiskinan yang melemahkan ketahanan keluarga, hambatan komunikasi orang dewasaremaja terkait kesehatan reproduksi, lingkungan sosial yang negatif serta minimnya alokasi waktu dan alat bantu pengajaran terkait kesehatan reproduksi remaja. Memperkuat ketahanan keluarga, meningkatkan kapasitas sekolah dalam memberikan pendidikan kesehatan reproduksi dan sensitisasi seluruh elemen masyarakat yang didukung oleh pemerintah merupakan solusi yang ditawarkan untuk mengeliminir masalah kesehatan reproduksi remaja.

$$
\text { Pembuat kebijakan dan }
$$
institusi pelayanan kesehatan seharusnya melibatkan orangtua, tokoh masyarakat dan guru dalam menyusun program kesehatan reproduksi untuk remaja. Hal ini agar program yang dibuat sesuai dengan kebutuhan dan kondisi lingkungan dimana remaja berada dan mendapat dukungan dari orang dewasa setempat.

\section{DAFTAR PUSTAKA}

Adamchak, S., Bond, K., MacLaren, L., Magnani, R., Nelson, K., Seilzer, J. (2000) A Guide to Monitoring and Evaluating Adolescent Reproductive Health Programs. FOCUS On Young Adult, Washington.

Awusabo-Asare, K., Bankole, A., KumiKyereme, A. (2008) Views of Adults on Adolescent Sexual and Reproductive Health: Qualitative Evidence from Ghana. New York. Tersedia pada: www.guttmacher.org.

Badan penelitian dan pengembangan kesehatan (2008) Riset Kesehatan Dasar 2007. Jakarta: Badan Penelitian dan Pengembangan Kesehatan,Kementerian Kesehatan RI.

Bakker, C, Elings-Pels, M., Reis, M. (2009) The Impact of Migration on Children in the Caribbean.UNICEF 
Barker, G. (2007) Adolescents, Social Support and Help-Seeking Behaviour Consultation with Recommendations for Action. Geneva: World Health Organization Press.

Blum, R.W., Astone, N.M., Decker, M.R., Mouli, V. C. (2014) "A conceptual Framework for Early Adolescence : a Platform for Research," Int J Adolesc Med Health, hal. 1-11. doi: 10.1515/ijamh2013- 0327.

Boamah-Kaali, E.A., Kaali, S., Manu, G., Gyaase, S., Adeniji, E., Owusu-Agyei, S., Asante, K. P. (2018) "Opinions of Health Professionals on Tailoring Reproductive Health Services to the Needs of Adolescents," International Journal of Reproductive Medicine, 2018, hal. 7. doi: $10.1155 / 2018 / 1972941$.

Demuth, A. (2013) Perception Theories. Diedit oleh A. Demuth,A.,Dolista,J.,Galivoka,S.,Garden fors,P.,Gray,R.,Petru.M.,Slavkovsky. Trnave: Edicia kognitivne studia.

Heriana,C.,Nurjannah,S.N., Suparman, R. (2015) "Distribusi Spasial dan Determinan Kejadian HIV/AIDS di Propinsi Jawa Barat Tahun 2014," Jurnal Ilmu-ilmu Kesehatan Bhakti Husada Kuningan, 4(2), hal. 1-9.

Hsieh, HF., Shannon, S. E. (2005) "Three Approaches to Qualitative Content Analysis," Qualitative Health Research, 15(9), hal. 1277-1288. doi: $10.1177 / 1049732305276687$.

Kementerian Kesehatan Republik Indonesia (2015) Profil Kesehatan Indonesia 2014. Jakarta: Kementerian Kesehatan RI.

Kementerian Pendidikan dan Kebudayaan RI (2012) Kurikulum 2013. Jakarta: Kementerian Pendidikan dan Kebudayaan RI.

Kibombo, R., Neema, S., Moore, A.M., Ahmed, F. H. (2008) Adults' Perceptions of Adolescents 'Sexual and Reproductive Health: Qualitative Evidence from Uganda. New York. Tersedia pada: www.guttmacher.org.
Komasari, D. Helmi, F. A. (2000) "Faktorfaktor Penyebab Perilaku Merokok Pada Remaja," Jurnal Psikologi, (1), hal. 3747.

Krippendorff, K. (2004) Content Analysis: An Introduction to Its Methodology. second. Diedit oleh J. Seawell,M.H., Meyers,J., Hoffman,C.A., Selhorst. California: Sage Publication.

Kumi-kyereme, A., Awusabo-asare, K., Darteh, E. K. M. (2014) "Attitudes of Gatekeepers Towards Adolescent Sexual and Reproductive Health in Ghana," African Journal of Reproductive Health, 18(3), hal. 142-153.

Latifah, L dan Anggraeni, M. D. (2013) "Hubungan Kehamilan Pada Usia Remaja dengan Kejadian Prematuritas, Berat Bayi Lahir Rendah dan Asfiksia," Jurnal Kesmasindo, 6(1), hal. 26-34.

Lloyd, C. B. (2005) Growing up Global. The Changing Transitions to Adulthood in Developing Countries. Washington: The National Academies Press. doi: 10.17226/11174.

Masroah, TI., Gamelia, E., Hariyadi, B. (2015) "Perilaku Seksual Remaja Akibat Paparan Media Pornografi," Jurnal Kesmasindo, 7(3), hal. 244-255.

Mohammadi Mohammad-Reza, Alikhani, S., Farahani, F.K.A., Bahonar, A. (2007) "Parents' Attitudes towards Adolescent Boy's Reproductive Health Needs and Practice in Tehran," Iran J Psychiatry, (2), hal. 13-24.

Moylan, S. et al. (2013) "The Impact of Smoking in Adolescence on Early Adult Anxiety Symptoms and the Relationship between Infant Vulnerability Factors for Anxiety and Early Adult Anxiety Symptoms : The TOPP Study," PLoS ONE, 8(5), hal. 1-11. doi: 10.1371.

Muhwezi, W.W., Katahoire, A. R., Banura, C., Mugooda, H.Doris, K. dan Bastien, S., Klepp, K. (2015) "Perceptions and Experiences of Adolescents, Parents and School Administrators Regarding Adolescent-Parent Communication on Sexual and Reproductive Health issues in Urban and Rural Uganda," Reproductive 
Health, 12(110), hal. 1-16. doi: 10.1186/s12978-015-0099-3.

Mumthas, N.S., S. E. (2016) "Problems among Adolescents in Northern Kerala Necessitates Adolescence Education," in National Conference on Prospects, Practices and Trends in Adolescence Education. Mysore.

Nundwe, C. S. (2012) Barriers to Communication Between Parents and Adolescents Concerning Sexual and Reproductive Health Issues: a Case Study of Kinondoni Municipality, Tanzania. Muhimbili University of Health and Allied Sciences.

Olubayo-Fatiregun, M. A. (2012) "The Parental Attitude towards Adolescent Sexual Behaviour in Akoko-Edo and EstakoWest Local Government Areas, Edo State ,Nigeria," World Journal of Education, 2(6), hal. 24-31. doi: 10.5430/wje.v2n6p24.

Ortiz-Echevarria, L., Greeley, M., Bawoke, T., Zimmerman, L., Robinson, C., Schlecht, J. (2017) "Understanding the Unique Experiences, Perspectives and Sexual and Reproductive Health Needs of Very Young Adolescents : Somali Refugees in Ethiopia," Conflict and Health, 11((Suppl 1)), hal. 36-65. doi: 10.1186/s13031-0170129-6.

Pemerintah Daerah Kabupaten Subang (2009) "Peraturan Daerah Kabupaten Subang Nomor 4 Tahun 2009." Subang, hal. 242. Tersedia pada: https://subang.go.id/assets/PRODUK_H UKUM/PERDA/2009 (Diakses: 20 Juni 2017).

Peraturan Pemerintah nomor 61 Tahun 2014 tentang Kesehatan Reproduksi (2014).

Pusat data dan Informasi Kementerian Kesehatan RI (2014) Situasi Kesehatan Ibu. Jakarta. Tersedia pada: www.depkes.go.id.
Putra, W. (15 November 2018) "Subang peringkat 4 di Jabar." Tersedia pada: https://www.mediajabar.com.diakses 15 Juli 2019

Rafidah, Emilia, O., Wahyuni, B. (2009) "Faktor-faktor yang Berhubungan dengan Pernikahan Usia Dini di Kabupaten Purworejo Jawa Tengah," Berita Kedokteran Masyarakat, 25(2), hal. 51-58.

Rahmawati, L. (12 Oktober 2018) "Remaja Kelompok Rentan Penularan Hiv/Aids Di Jawa Barat." Tersedia pada: https://aidsjabar.or.id.diakses 15 Juli 2019

Rondina, CR., Gorayeb, R., Botelh, C. (2007) "Psychological Characteristics Associated with Tobacco Smoking Behavior," J Bras Pneumol, 33(5), hal. 592-601.

Save the Children (2004) Children Having Children: State of the Worlds Mothers 2004. Westport.

Steinberg, L. dan Morris, A. S. (2001) "Adolescent Development," Annu. Rev. Psychol, 52, hal. 83-110.

Svodziwa, M., Kurete, F. dan Ndlovu, L. (2016) "Parental Knowledge, Attitudes and Perceptions towards Adolescent Sexual Reproductive Health in Bulawayo," International Journal of Humanities Social Sciences and Education, 3(4), hal. 62-71. doi: 2349-0381.0304007.

United Nations Population Fund \& Save the Children (2009) Adolescent Sexual and Reproductive Health.Toolkit for Humanitarian Settings. Westport.

World Health Organization (2014) Global Status Report on Alcohol and Health 2014. Diedit oleh D. Poznyak, V., Rekve. Geneva: WHO Press. 